\title{
Monitoring of sensory attributes used in the quality payment system of Trentingrana cheese
}

\author{
G. Bittante, ${ }^{\star}$ N. Cologna, ${ }^{\star}$ A. Cecchinato, ${ }^{\star}$ M. De Marchi, ${ }^{\star}$ M. Penasa, ${ }^{\star 1}$ F. Tiezzi, ${ }^{\star}$ I. Endrizzi, $†$ and F. Gasperi† \\ *Department of Animal Science, University of Padova, Viale dell'Università 16, 35020 Legnaro (PD), Italy \\ †IASMA Research and Innovation Centre, Fondazione Edmund Mach, Food Quality and Nutrition Area, Via E. Mach 1, \\ 38010 S. Michele all'Adige (TN), Italy
}

\section{ABSTRACT}

Trentingrana is a Protected Designation of Origin (PDO) hard cheese manufactured in the valleys of Trento province (eastern Italian Alps) by several small cooperative dairies linked in a consortium. Nine months after production, wheels are delivered to a shared facility, ripened up to $18 \mathrm{mo}$, and assessed by a panel of 8 experts for 7 sensory attributes; namely, external aspect, rind thickness, paste color, texture, odor, taste, and aroma. The evaluation takes place every 2 mo on wheels sampled within each dairy. Based on the results of the assessment, dairies receive a price premium or penalty depending on a quality index, which is the weighted sum of the scores attributed to each sampled wheel. Sensory scores and quality index of 652 wheels representing 11 dairies and $10 \mathrm{yr}$ of production were analyzed using a model that included fixed effects of dairy, year, and season of production, and first-order interactions between them. The coefficients of determination ranged from 0.50 (texture) to 0.66 (aroma). All factors significantly affected the studied traits, with the exception of interactions between dairy and season of production for texture and external aspect, and between year and season of production for odor. Dairy was the most important source of variation for visually assessed traits (external aspect, rind thickness, paste color, and texture) and for quality index, whereas year of production was the most important for flavor attributes (odor, taste, and aroma). The latter traits were always highly correlated among them and with the quality index, whereas correlations among visually assessed attributes, between them and flavor attributes, and between them and the quality index were more erratic. The sensory evaluation performed by the panel of experts has proven to be a useful tool to define the quality index and address the payment system of

Received February 28, 2011.

Accepted July 5, 2011.

${ }^{1}$ Corresponding author: mauro.penasa@unipd.it
Trentingrana cheese, but it has some limitations in correctly describing the sensory profile of cheese and identifying specific defects and possible remedies.

Key words: dairy factory, payment system, sensory attribute, Trentingrana cheese

\section{INTRODUCTION}

Because of strict regulations imposed on milk origin and production techniques, Protected Designation of Origin (PDO) cheeses are often variable and their quality may depend on the farming system, cow breed, dairy factory, geographical area, season, and year (Bertoni et al., 2001). Protected Designation of Origin constraints increase production costs but they represent an opportunity to achieve a premium price for the product (Bouamra-Mechemache and Chaaban, 2010). In PDO cheeses, systematic control of quality is essential to monitor the production chain so that satisfactory prices can be established and maintained (Delahunty and Piggott, 1995; Noel et al., 1998; Elortondo et al., 1999, 2007; Galgano et al., 2001).

A representative example of a $\mathrm{PDO}$ product is the Trentingrana (also known as "Grana Trentino"), an Italian hard, cooked cheese produced using partially skimmed raw cow milk acidified using a natural starter culture. The starter is obtained from the spontaneous fermentation of part of the previous day's whey (Franciosi et al., 2011). Wheels have a typical granular texture and a distinctive flavor profile developed over a ripening period of at least 18 mo (Salvadori Del Prato, 1994; Boscaini et al., 2003). Trentingrana is a secondary label of Grana Padano and can be produced only in a restricted area, the Trento province (eastern Italian Alps), where cheese is the most important dairy product $(4,000 \mathrm{t} / \mathrm{yr})$. The environment of production (mountainous area), restrictions in cow feeding (silages are forbidden), and traditional manufacturing protocols (lysozyme is not allowed) are the main features contributing to the uniqueness of the cheese. On average, herds supplying milk to dairies for Trentingrana are 
small; $87 \%$ of them have fewer than 30 cows and the major breeds are Italian Brown Swiss, dual-purpose Italian Simmental, and local populations (Rendena and Alpine Grey). In recent years, the proportion of milk from larger and more specialized dairy farms, mainly rearing Holstein-Friesian cows, has been growing.

Trentingrana is produced by several small dairy cooperatives linked in a consortium whose official inspectors, about 9 and 18 mo after production, evaluate all wheels individually and classify them as "first quality," "second quality," and "discarded" (Bittante et al., 2011). Firstquality wheels from each dairy are then sampled and assessed by a panel of experts for traditional sensory attributes. The consortium sells the first-quality cheese of participating dairies and rewards or penalizes them using price premiums or penalties according to results of the sensory evaluation. In particular, the experts check if the product complies with stated requirements, evaluating the presence of defects as well as of positive sensory characteristics; based on the assessment, the product is graded in different levels of sensory quality, from standard to excellent. The members of the panel have consolidated experience in tasting cheese, especially Grana-type cheese, so they have developed notable skills to evaluate the sensory characteristics of the product but have not been given systematic training and do not use standardized methods. This is a common approach of many sensory committees of PDO products (Elortondo et al., 2007) and is one of the most controversial strategies used in sensory quality control (Costell, 2002). The disadvantages of this approach are well known: the perceptiveness can vary from day to day and a panelist's judgment may change under the influence of external factors (Feria-Morales, 2002). The practical value of the information obtained from a quality control system based on sensory evaluation depends on the correct fulfillment of some important requirements: (1) the selection of the sensory quality standard; (2) the establishment of the sensory specification; (3) the set-up of the sample preparation and evaluation procedure; (4) the selection, training, and maintenance of the panel; and (5) the experimental design to control product, judges, and replicate effects.

This paper is part of a wider research project that seeks to analyze the production chain of Trentingrana cheese. Specifically, the objective of the study was to investigate sources of variation in the sensory traits chosen to monitor the quality level and quality index used for payment of Trentingrana cheese. Moreover, the adequacy of the current evaluation system to give a sensory description of the product and to be used as a management tool by dairy factories is critically discussed.

\section{MATERIALS AND METHODS}

\section{Field Data}

The small dairy cooperatives that produce PDO Trentingrana cheese are linked in the Consortium of Dairy Factories of Trento province (Italy). At about 9 mo from production, official consortium inspectors visit each dairy and evaluate all wheels individually according to external aspects (color, integrity, presence of mold, swelling) and the sound obtained by beating the wheel with a special hammer to recognize inner holes or imperfections (Bittante et al., 2011). Based on results of this evaluation, wheels are classified as "first quality," "second quality," and "discarded." The cheese is then delivered to a shared facility and ripened up to at least 18 mo when a second, identical evaluation takes place. Then, a second type of quality assessment is carried out, namely the evaluation of some sensory attributes, which is performed by a panel of experts on first-quality wheels sampled from each dairy. Since 1999, the Consortium sells the first-quality wheels of participating dairies and rewards or penalizes them using price premiums or penalties according to results of the sensory evaluation.

The Consortium provided us with data on the sensory attributes of Trentingrana cheese recorded during the period 2000-2010 on wheels produced by 11 dairy factories from 1999 to 2008 . The quality assessment was based on a traditional sensory evaluation (approved by the Consortium) that was performed 6 times over any calendar year and dairy, so that the quality of cheese manufactured in a 2-mo period could be monitored. We used data editing to extract the evaluation of 1 Trentingrana wheel for each 2-mo period, year, and dairy factory, leading to a total of 660 wheels. Eight wheels were discarded because of missing or incomplete data, so that the final data set included information on 652 wheels.

Traditional sensory evaluation was conducted by a panel of 8 experts involved in several aspects of cheese production and marketing. The experts assessed wheels using a protocol featuring 7 parameters: external aspect, rind thickness, paste color, texture, odor, taste, and aroma. The list of attributes evaluated by the panel and their description are summarized in Table 1. Traits were assessed using score charts based on a 10 -point scale $(1=$ very bad/unacceptable and $10=$ very good/excellent; from 1 to 5 points the judgment is negative, from 6 to 10 positive), but, in practice, only scores from 3 to 10 were awarded by the panel, because only wheels classified as first quality were assessed. For each wheel, the scores given to each trait by the experts were averaged and a quality index was calculated as the 
Table 1. List of sensory attributes of Trentingrana cheese judged by the panel of experts ${ }^{1}$

\begin{tabular}{|c|c|c|}
\hline Attribute & Instruction & Weighting \\
\hline External aspect & $\begin{array}{l}\text { - the regularity of wheel shape, its surface integrity, the uniformity } \\
\text { and type of crust color, the degree of definition of trademark }\end{array}$ & 1.0 \\
\hline Rind thickness & - the crust thickness & 1.0 \\
\hline Paste color & - the color of paste and its degree of uniformity between the various parts of the section & 1.3 \\
\hline Texture & - the degree of grain fineness of paste microstructure & 1.0 \\
\hline Evaluation by tasting & $\begin{array}{l}\text { The judge samples some cheese pieces from different zones (in correspondence to the central } \\
\text { and the external sides of the wheel), tastes and evaluates the following characteristics: }\end{array}$ & \\
\hline Taste & $\begin{array}{l}\text { - the quality of taste sensation, based on the intensity and } \\
\text { equilibrium of basic tastes (salty, acid, sweet, bitter) }\end{array}$ & 1.8 \\
\hline Aroma & $\begin{array}{l}\text { - the quality of flavor sensation, based on the intensity and equilibrium of sensation } \\
\text { perceived during the chewiness and after the swallowing relating to odor retronasal } \\
\text { perception (caused by the presence of typical aromas related to ripened grana cheese } \\
\text { and by the absence of anomalous aromas related to defects of fermentation) }\end{array}$ & 1.7 \\
\hline
\end{tabular}

${ }^{1}$ For each parameter, the evaluation instructions are given and the weight used in the definition of the quality index is reported. The anchors on the 10-point scale are $1=$ very bad/unacceptable and $10=$ very good/excellent; from 1 to 5 points the judgment is negative, and from 6 to 10 positive.

weighted sum of the average scores received by each sampled wheel. Weightings considered for each sensory trait to calculate the index, with respect to their relative importance, are reported in Table 1. The quality index has traditionally been used by the Consortium to establish price premiums or penalties for Trentingrana cheese produced by associated dairies.

\section{Statistical Analysis}

An ANOVA was carried out on sensory attributes and quality index using the GLM procedure (SAS Inst. Inc., Cary, NC) according to the following linear model:

$$
\begin{gathered}
y_{\mathrm{ijk} l}=\mu+D_{\mathrm{i}}+\mathrm{Y}_{\mathrm{j}}+\mathrm{S}_{\mathrm{k}}+(\mathrm{D} \times \mathrm{Y})_{\mathrm{ij}} \\
+(\mathrm{D} \times \mathrm{S})_{\mathrm{ik}}+(\mathrm{Y} \times \mathrm{S})_{\mathrm{jk}}+\varepsilon_{\mathrm{ijk} \mathrm{l}},
\end{gathered}
$$

where $\mathrm{y}_{\mathrm{ijkl}}$ is the observed trait; $\mu$ is the overall intercept of the model; $D_{i}$ is the fixed effect of the ith dairy factory ( $\mathrm{i}=1$ to 11$) ; \mathrm{Y}_{\mathrm{j}}$ is the fixed effect of the $\mathrm{jth}$ year of production ( $\mathrm{j}=1999$ to 2008); $\mathrm{S}_{\mathrm{k}}$ is the fixed effect of the kth season of production ( $\mathrm{k}=1$ to 6$) ;(\mathrm{D} \times$ $\mathrm{Y})_{\mathrm{ij}}$ is the fixed interaction effect between dairy factory and year of production; $(\mathrm{D} \times \mathrm{S})_{\mathrm{ik}}$ is the fixed interaction effect between dairy factory and season of production; $(\mathrm{Y} \times \mathrm{S})_{\mathrm{jk}}$ is the fixed interaction effect between year and season of production; and $\varepsilon_{\mathrm{ijk}}$ is the random residual $\mathrm{N} \sim\left(0, \sigma_{\mathrm{e}}^{2}\right)$. The season effect was classified into 6 bimonthly classes (January and February, March and April, May and June, July and August, September and October, November and December). The level of significance was set to $P<0.05$.
Pearson correlations between the traits were estimated using raw data, LSM of the fixed effects of dairy, year of production, and season of production, and using residuals through the CORR procedure (SAS Inst. Inc.). The level of significance was set to $P<0.05$.

\section{RESULTS AND DISCUSSION}

The descriptive statistics shown in Table 2 indicate that the average scores for traditional sensory attributes of Trentingrana cheese were positive in all instances, ranging from 7.04 for aroma to 7.70 for texture. The SD approached 0.50 points for most traits, although much lower variability was found for texture $(\mathrm{SD}=0.37$; CV $=4.8 \%$ ), whereas external aspect showed higher variability $(\mathrm{SD}=0.74 ; \mathrm{CV}=9.7 \%)$. All traditional sensory attributes were characterized by left-skewed and leptokurtic distributions, with relevant differences among traits: paste color, texture, and rind thickness exhibited values $<-1.0$ for skewness and $>1.0$ for kurtosis, whereas aroma showed a more normal distribution. The quality index averaged 70.0 points, slightly above the value of 68.0 assumed as a reference by the Consortium to define the base price of first-quality Trentingrana cheese. The SD was $3.50(\mathrm{CV}=5.0 \%)$, and skewness and kurtosis were intermediate to those calculated for sensory attributes (Table 2). Taking into account the price premiums/penalties payment scheme adopted by the Consortium (Figure 1), a change in quality index of 1 SD unit resulted in a premium/penalty of $€ 0.181 /$ $\mathrm{kg}$ of first-quality cheese. Considering that the average price paid by the Consortium to dairy factories during the period of the study was $€ 6.523 / \mathrm{kg}$, a variation of 


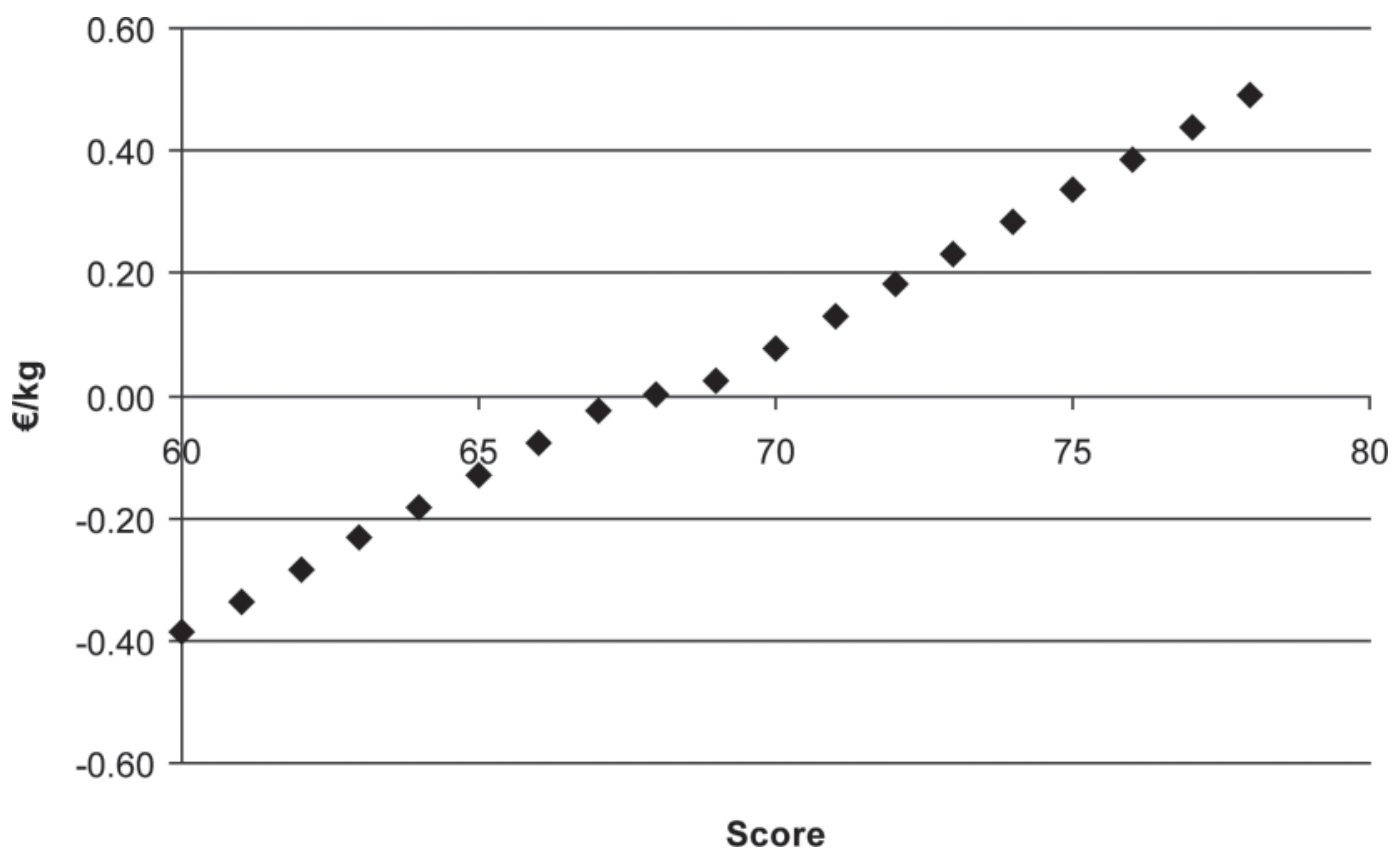

Figure 1. Effect of quality index on price premiums/penalties $(€ / \mathrm{kg})$ of first-quality wheels of Trentingrana cheese.

$10 \%$ of the quality index (2 SD units) would lead to a price variation of $5.5 \%$.

The ANOVA (Table 3) showed that effects included in the model explained $50 \%$ (texture) to $66 \%$ (aroma) of total variability. Significance was found for all factors $(P<0.05)$, except for interactions between dairy factory and season of production for external aspect and texture, and between year and season of production for odor. The residual SD of traditional sensory attributes ranged from 0.32 points for texture and odor to 0.58 points for external aspect, and was 2.68 points for the quality index.

As expected, Pearson correlations among raw data showed that the quality index was positively correlated $(P<0.001)$ with all its component traits (Table 4$)$, particularly odor, taste, and aroma. This was not only because these attributes carried the highest weights (Table 1), but also because they were highly correlated among them (Table 5). Thus, odor, taste, and aroma of
Trentingrana cheese are the main drivers of price premiums/penalties paid to dairies, whereas visually assessed parameters have a lesser effect on the economic value of cheese. Tables 4 and 5 show that correlations among the residuals were very close to those obtained using raw data.

\section{Effect of Dairy Factory}

The dairy factory was the most important source of variation of visually assessed traits (external aspect, rind thickness, paste color, and texture) and quality index, and the second most influential component of flavor attributes (odor, taste, and aroma) of Trentingrana cheese (Table 3). Figure 2 ranks the participating dairies from the worst to the best according to the quality index; it is worth noting that the ranking for most attributes was very similar to that of the quality index. This is also confirmed by Pearson correlations between

Table 2. Descriptive statistics of sensory attributes and quality index of Trentingrana cheese $(\mathrm{n}=652)$

\begin{tabular}{lcccccc}
\hline Attribute & Mean & SD & Minimum & Maximum & Skewness & Kurtosis \\
\hline External aspect & 7.65 & 0.74 & 4.40 & 9.86 & -0.47 & 0.62 \\
Rind thickness & 7.44 & 0.54 & 4.50 & 9.00 & -1.00 & 3.08 \\
Paste color & 7.54 & 0.55 & 3.17 & 8.83 & -1.34 & 7.37 \\
Texture & 7.70 & 0.37 & 5.50 & 8.67 & -1.10 & 3.37 \\
Odor & 7.34 & 0.41 & 5.33 & 8.20 & -0.20 & 0.45 \\
Taste & 7.20 & 0.54 & 4.67 & 9.00 & -0.18 & 0.80 \\
Aroma & 7.04 & 0.55 & 4.83 & 8.67 & -0.09 & 0.15 \\
Quality index & 70.0 & 3.50 & 47.8 & 79.3 & -0.57 & 2.15 \\
\hline
\end{tabular}


Table 3. Results from ANOVA ( $F$-value and significance) for sensory attributes and quality index of Trentingrana cheese

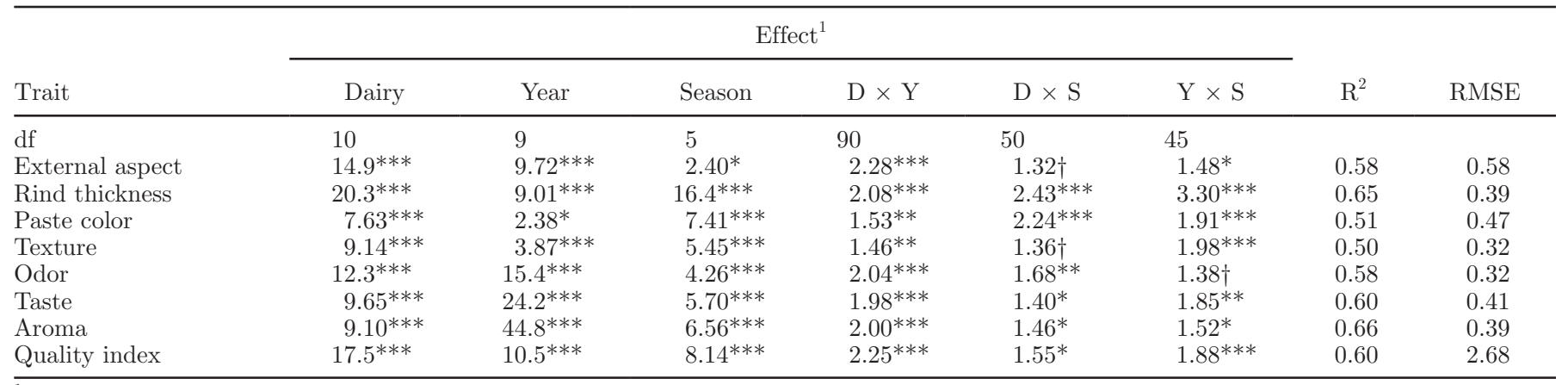

${ }^{1} \mathrm{D} \times \mathrm{Y}$ is the interaction effect between dairy factory and year of production; $\mathrm{D} \times \mathrm{S}$ is the interaction effect between dairy factory and season of production; $\mathrm{Y} \times \mathrm{S}$ is the interaction effect between year and season of production. RMSE = root mean square error.

$\dagger P<0.10 ;{ }^{*} P<0.05 ;{ }^{* *} P<0.01 ; * * * P<0.001$.

quality index and sensory attributes computed on LSM of the dairy effect (Table 4$)$, which were positive and high $(P<0.05)$. Correlations among traditional sensory attributes computed using the LSM of the dairy effect were positive and moderate to high, ranging from 0.43 (external aspect with taste) to 0.98 (odor with aroma and taste with aroma; Table 5); significance was found in all cases except for correlations between external aspect with paste color, odor, taste, and aroma.

Dairy factory was also found to be the most important source of variation when experts of the Consortium identified first-quality Trentingrana wheels (Bittante et al., 2011), and when quality characteristics of other cheeses were evaluated (Bellesia et al., 2003; Drake et al., 2008). The processing of milk and cheese are very similar among dairies because all of them adhere to PDO rules. However, possible explanations of the strong influence of dairies on studied traits could be related to several aspects. Cooperative dairies largely differed in terms of number of associated herds, level of production of these herds, amount of milk processed daily, number of wheels manufactured (Bittante et al., 2011), and the procedure of transportation of milk. Small farmers usually deliver milk using 30 - or $50-\mathrm{L}$ cans, whereas larger farms use refrigerated tanks. In addition, technological aspects such as the time given to milk for creaming varies from 6 to $10 \mathrm{~h}$ depending on the dairy.

Variation in characteristics of processed milk is another important aspect that may explain differences among dairies, because farming systems change across valleys and highlands of Trento province in terms of altitude, breeds, and use of summer Alpine pastures. Analyses performed on bulk milk used for manufacturing Trentingrana cheese identified highly significant differences among dairies with respect to fat, protein, and urea contents, SCS, and total bacterial and clostridial counts (Cologna et al., 2010), whereas hygienic conditions of raw milk were good (Franciosi et al., 2009). Both farming system and feeding regimen significantly influenced milk composition and physical and sensory attributes of PDO and traditional cheeses (Agabriel et al., 2004; Tornambè et al., 2005).

\section{Effect of Year of Production}

Statistical analysis revealed that year of production was important $(P<0.05)$ in explaining the variation

Table 4. Pearson correlations ${ }^{1}$ between the quality index and sensory attributes of Trentingrana cheese

\begin{tabular}{llllll}
\hline Correlation & Raw & Dairy & Year & Season & Residual \\
\hline Quality index with: & & & & & \\
External aspect & $0.37^{* * *}$ & $0.69^{*}$ & -0.40 & 0.18 & $0.37^{* * *}$ \\
Rind thickness & $0.43^{* * *}$ & $0.88^{* * *}$ & -0.53 & 0.68 & $0.38^{* * *}$ \\
Paste color & $0.72^{* * *}$ & $0.90^{* * *}$ & 0.45 & $0.96^{* *}$ & $0.71^{* * *}$ \\
Texture & $0.67^{* * *}$ & $0.91^{* * *}$ & 0.17 & $0.82^{*}$ & $0.66^{* * *}$ \\
Odor & $0.86^{* * *}$ & $0.94^{* * *}$ & $0.96^{* * *}$ & $0.85^{* *}$ & $0.83^{* * *}$ \\
Taste & $0.87^{* * *}$ & $0.91^{* * *}$ & $0.90^{* * *}$ & $0.96^{* *}$ & $0.87^{* * *}$ \\
Aroma & $0.84^{* * *}$ & $0.94^{* * *}$ & $0.93^{* * *}$ & $0.91^{*}$ & $0.87^{* * *}$ \\
\hline
\end{tabular}

${ }^{1}$ Raw $=$ correlations between raw data of each wheel evaluated; Dairy = correlations between least squares means of the dairy effect; Year = correlations between least squares means of the year of production effect; Season $=$ correlations between least squares means of the season of production effect; Residual = correlations between the residuals of each wheel evaluated.

${ }^{*} P<0.05$; ** $P<0.01$; *** $P<0.001$. 
Table 5. Pearson correlations ${ }^{1}$ between sensory attributes of Trentingrana cheese

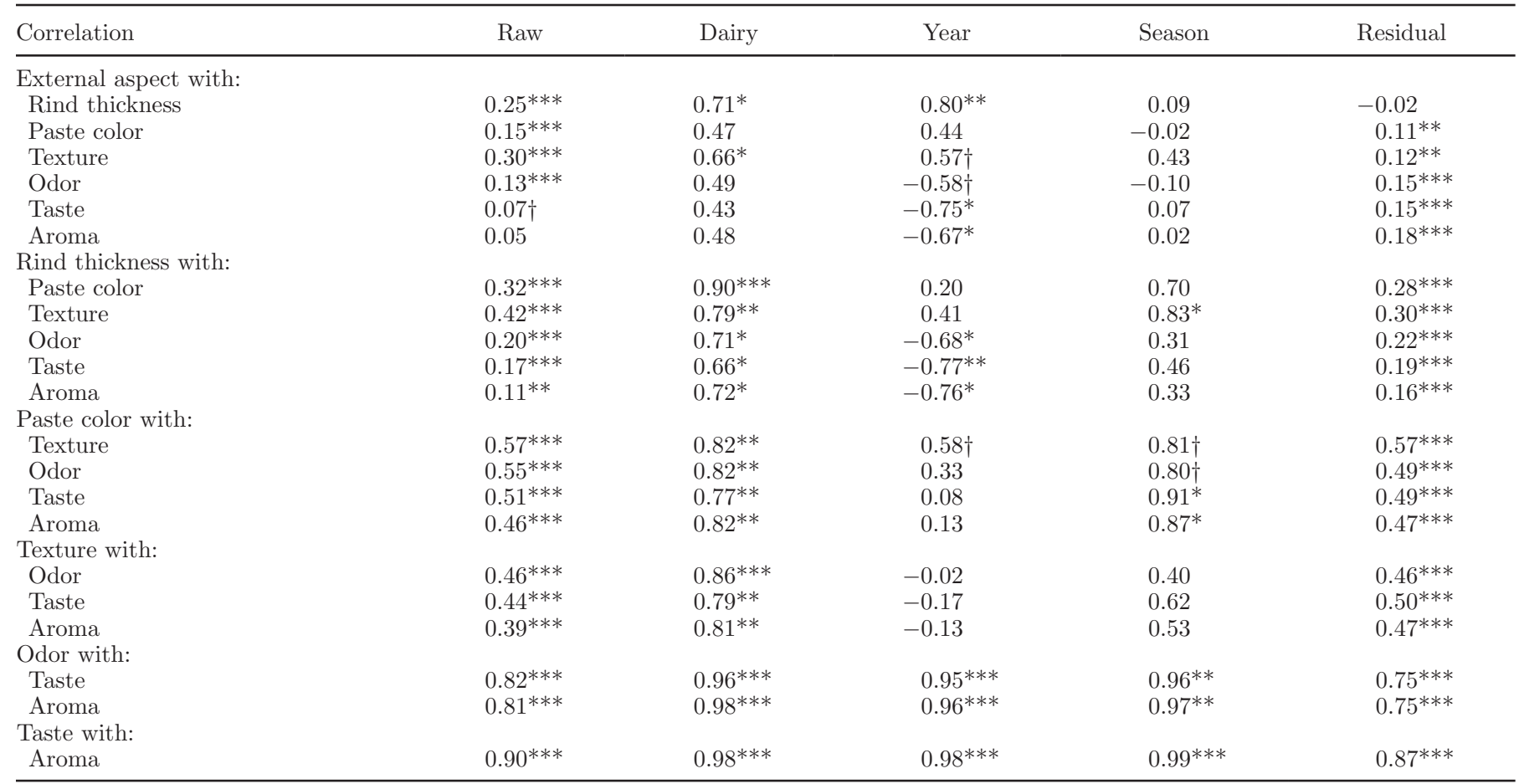

${ }^{1}$ Raw = correlations between raw data of each wheel evaluated; Dairy = correlations between least squares means of the dairy effect; Year $=$ correlations between least squares means of the year of production effect; Season $=$ correlations between least squares means of the season of production effect; Residual = correlations between the residuals of each wheel evaluated.

$\dagger P<0.10 ; * P<0.05 ;{ }^{* *} P<0.01 ; * * * P<0.001$.

of traditional sensory attributes and quality index of first-quality wheels of Trentingrana cheese (Table 3). The quality index was stable in early years (Figure 3), followed by a sharp decline from 2002 to 2007, and a partial recovery in 2008. A similar trend was detected for flavor traits, whereas visual attributes showed fewer changes across the years (Figure 3). During the same period, the average price of first-quality cheese paid to dairies showed variation in the range of $10 \%$ between the maximum and minimum values (Figure 3). Pearson correlations computed on LSM of the year effect confirmed that the quality index was strongly, positively, and significantly $(P<0.001)$ correlated with flavor attributes, but not with visually assessed traits (Table 4). In addition, correlations among flavor parameters computed on LSM of the year effect were positive, very strong, and highly significant $(P<0.001)$, whereas correlations among visual attributes, and between them and flavor attributes were more erratic, and significance was reached in only a few cases (Table 5).

Year of production was also found to be highly significant in explaining the variability of the percentage of first-quality wheels of Trentingrana cheese (Bittante et al., 2011), but the pattern differed from that described above. Indeed, the percentage of wheels classified as first quality decreased from 2002 to 2005, and recovered thereafter. Further research is needed to explore reasons that led to worsened flavor attributes and quality index of cheese over years. As the evaluation chart of each attribute is not based on objective references, we cannot exclude the possibility that the decrease of the average scores over years depended, in part, on a higher strictness of experts in judging the wheels rather than on the quality of cheese. Moreover, such research is difficult because the evaluation system of the Consortium seeks to assess product desirability in the absence of any precise description of major features of the sensory profile (Drake, 2004, 2007; Foegeding and Drake, 2007). Thus, although it appears that the odor desirability of Trentingrana cheese is deteriorating, we cannot identify the particular odor causing the adverse effect (Bodyfelt et al., 2008). If traditional sensory evaluation is indeed still regarded as useful in the commercial evaluation of cheese, the procedure has reduced value when viewed as a method of improving the Trentingrana production chain (Nielsen et al., 1998; Costell, 2002; Feria-Morales, 2002; Elortondo et al., 2007).

During the 10-yr study period, dairy techniques remained substantially unchanged, mainly because of a perceived need to rigidly follow the PDO production 
(a)

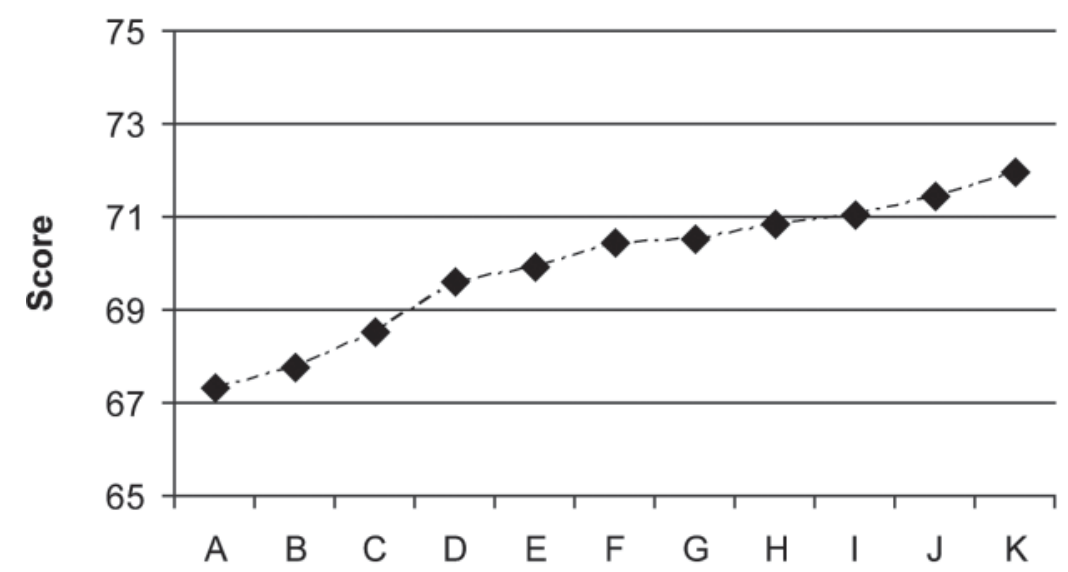

(b)

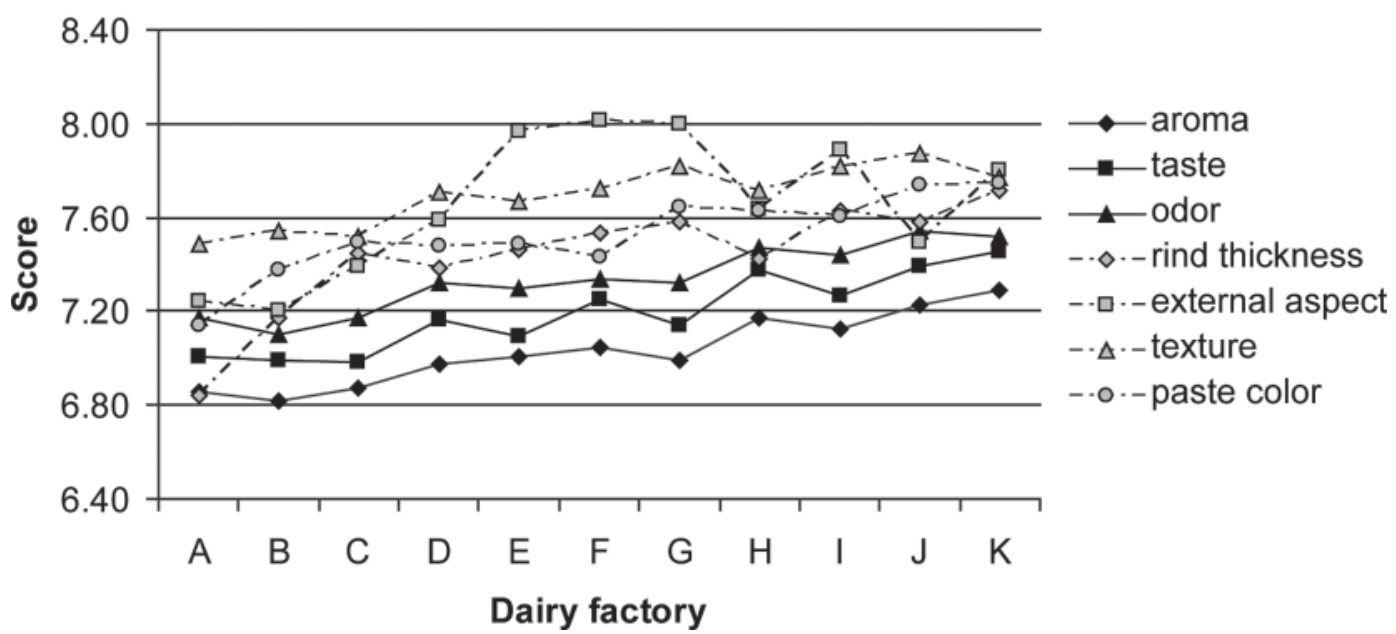

Figure 2. Least squares means of (a) quality index and (b) sensory attributes of Trentingrana cheese across dairy factories. Dairies are ordered according to least squares means of the quality index.

rules. However, the number of farms delivering milk to cooperative dairies decreased, and both the quantity of milk processed daily and the number of wheels produced increased gradually (Bittante et al., 2011). The average amount of milk delivered by associated farms to dairies increased, mainly because of a progressive substitution of traditional Alpine breeds such as Brown Swiss with Holstein-Friesian. Moreover, changes in the genetics of animals within breed, feeding strategies, and rearing systems have been shown to influence the sensory features of PDO cheeses (Agabriel et al., 2004). These developments raise relevant questions of the future of the Trentingrana industry because milk from Holstein-Friesian cows is characterized by lower fat and protein contents. However, bulk milk delivered to dairies during the study period has trended higher in both fat and protein contents and lower in overall bac- terial and clostridial count; only the trend of SCS was unfavorable (Cologna et al., 2010). Likely, any negative effect of the increased number of Holstein-Friesian cows on milk contents is balanced by a long-term positive genetic trend in all breeds reared in the province, and by the beneficial environmental effects induced by intensification.

The use of Holstein-Friesian milk reduces cheese yield compared with Brown Swiss (Malacarne et al., 2006), even after adjustment for fat and protein content (De Marchi et al., 2008). In addition, milk from the former breed is characterized by poorer coagulation properties (rennet coagulation time and curd firmness) compared with that from Alpine breeds (De Marchi et al., 2007); this is an important aspect to bear in mind because clotting characteristics influence both cheese yield and sensory attributes (Ng-Kwai-Hang et al., 1989; Martin 
(a)

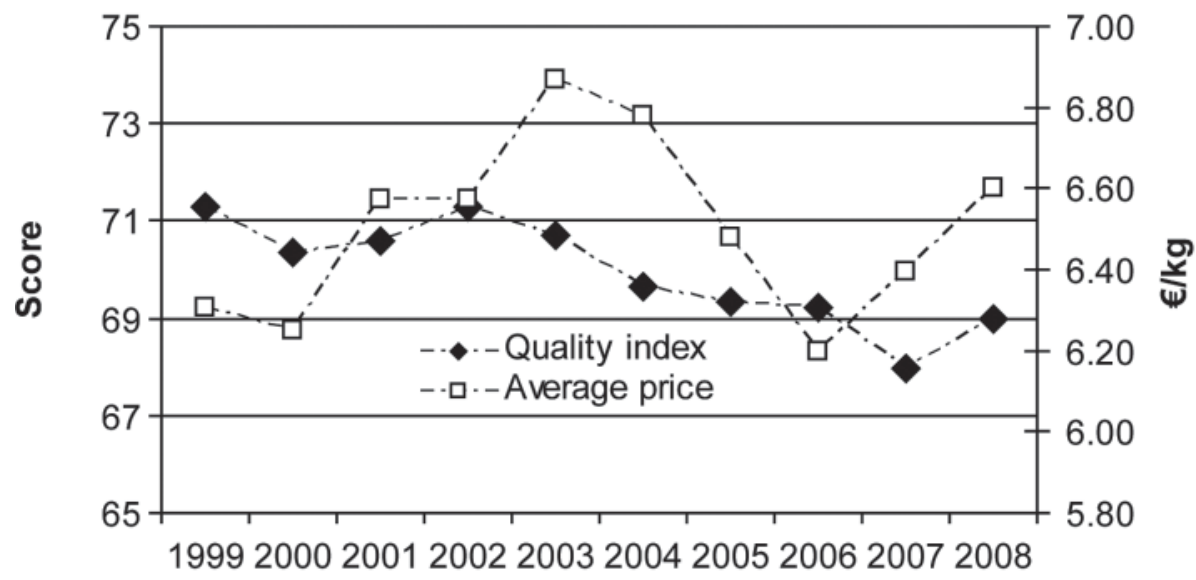

(b)

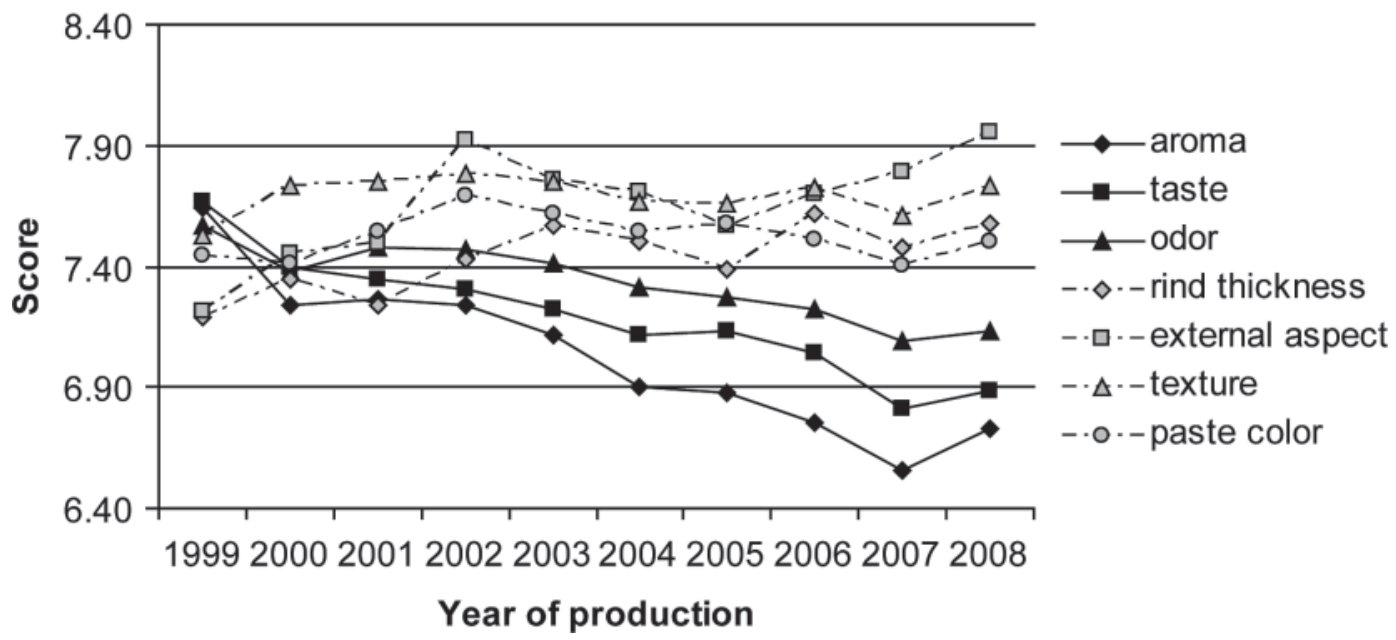

Figure 3. Least squares means of (a) quality index and average price $(€ / \mathrm{kg})$ paid to dairies, and (b) sensory attributes of Trentingrana cheese across years of production.

et al., 1997). Currently, breeds reared in Trento province are not selected for enhanced coagulation ability, although rennet coagulation time and curd firmness have been shown to be heritable in Holstein-Friesian (Oloffs et al., 1992; Comin et al., 2005; Cecchi et al., 2007; Cassandro et al., 2008; Vallas et al., 2010) and Brown Swiss (Cecchinato et al., 2009), and they are used in the quality payment scheme of milk in the province. Recent studies have reported that genetic improvement of milk coagulation ability could be cheaply and efficiently achieved at the population level using mid-infrared spectrometry (Dal Zotto et al., 2008; Cecchinato et al., 2009; De Marchi et al., 2009). In Italian Brown Swiss cows, indirect improvement of coagulation properties may be expected because of the inclusion of $\kappa$-casein genetic variants in the selection index; it is accepted that allele $\mathrm{B}$ of $\kappa$-casein elevates desirable coagulation properties (Aleandri et al., 1990; Comin et al., 2008; Penasa et al., 2010), mainly by increasing the proportion of $\kappa$-casein in milk (Bonfatti et al., 2010). Thus, trends in rennet coagulation time and curd firmness must be monitored, and any possible relationship with cheese yield, composition, and sensory quality should be further investigated.

\section{Effect of Season of Production}

Season of production significantly $(P<0.05)$ influenced all sensory attributes and the quality index of Trentingrana cheese (Table 3). With the exception of external aspect, the highest average scores for sensory parameters were found for wheels produced from Janu- 
(a)

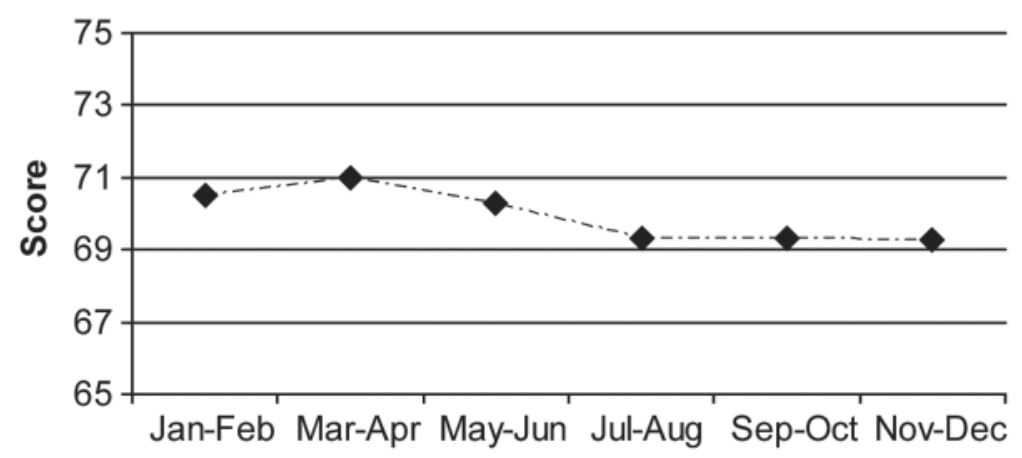

(b)

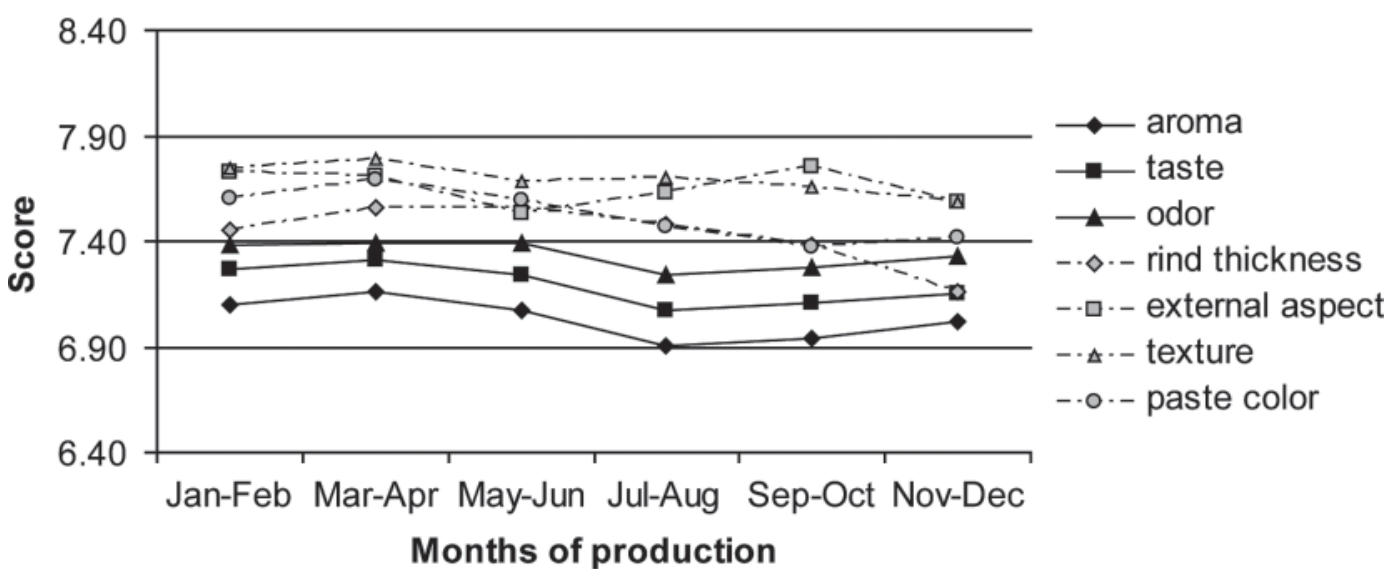

Figure 4. Least squares means of (a) quality index and (b) sensory attributes of Trentingrana cheese across seasons of production.

ary to June (Figure 4). The trend is similar to that observed for the percentage of Trentingrana wheels classified as first quality (Bittante et al., 2011). Thus, cooperative dairies achieved their best and most profitable results in spring for both evaluations.

Because of seasonal variations in component traits, the quality index showed a circannual trend, with the highest scores from January to June and the lowest from July to December (Figure 4), similar to the trends for individual sensory attributes. Similar results were obtained by Gaya et al. (2003) for Castellano cheese. Large seasonal variations in sensory properties are often found in PDO cheeses, especially if they are produced in mountain or extensive farming systems (Mendia et al., 2000; Polentarutti et al., 2001; Agabriel et al., 2004; Segato et al., 2007).

To understand seasonal variation, it should be noted that Trentingrana cheese is a typical PDO product obtained in mountain areas according to traditional techniques and mainly using milk from small farms. Hence, the cow feeding regimen is not constant during the year, although it essentially relies on hay and con- centrates. As previously mentioned, silages are forbidden because of the risk of contamination of milk with clostridia that can lead to off-flavors and excessive gas formation (late-blowing) in cheese. In addition, milk produced during summer on high pastures cannot be used to produce Trentingrana because it is very variable in quality (Buchin et al., 1999). Moreover, according to tradition, several farmers rearing Alpine breeds transfer the entire herd to the high pastures during summer, and therefore, seasonality of production is evident. Inseminations are predominantly performed in winter, followed by late lactation and dry period in summer, and calving in autumn when the herd comes back to the permanent farm. The obvious consequence of this management strategy is that seasonal variation of sensory attributes and milk quality traits reflects not only climatic aspects such as temperature and humidity, but also changes in lactation stage, feeding regimen, housing systems, and breed proportion in lactating cows (Agabriel et al., 2004; Coulon et al., 2005; Martin et al., 2005, 2009). This latter group of factors probably explains the significant interactions between year and 
season of production (Table 3), whereas interactions between dairy and year and between dairy and season are probably attributable to variations in the level of farming intensification in the valleys of Trento province.

Pearson correlations between the quality index and sensory traits of Trentingrana cheese computed on LSM of season effect were positive, high, and significant $(P$ $<0.05)$, with the exception of external aspect and rind thickness (Table 4). When relationships among sensory attributes based on LSM of the season effect were considered, only a few parameters were significantly correlated, particularly those involving odor, taste, and aroma $(P<0.01$; Table 5$)$.

\section{CONCLUSIONS}

The scores for the 7 sensory attributes and the quality index used to determine price premiums or penalties of Trentingrana cheese varied according to dairy factory, year and season of production, and interactions between these sources of variation. Apart from seasonal variations, which must be regarded as inevitable when the quality of cheese produced in a mountain environment from milk obtained from small traditional farms is examined, our study shows a decrease of scores for flavor parameters over the years. This negative trend does not appear to be attributable to any change in dairy production technology, but rather to intensification of dairy farming, even if we cannot exclude a slow change in evaluation criteria by experts; thus, further investigations are required to better ascertain this issue. The major limitation of the evaluation system adopted by the Consortium is the lack of a precise description of sensory attributes according to sensory profiling methods. The traits evaluated by the experts reflect subjective judgments on a not-so-clearly defined spectrum between desirability and undesirability, and do not employ analytical sensory descriptors. Even if sensory evaluation is useful in monitoring the overall quality of Trentingrana cheese, defining the quality index, and addressing price premiums or penalties for the cheese, the process fails to identify the specific problems causing changes in cheese attributes, and thus does not assist in understanding why quality is deteriorating or how the problem can be addressed. Another limitation is the lack of a reference chart that anchors individual scores to objective values. An analytical rigorous descriptive sensory analysis system based on a trained panel for the evaluation of Trentingrana cheese has to be developed, and such a tool should be implemented to systematically monitor cheese production in cooperative dairies.

\section{ACKNOWLEDGMENTS}

This study was carried out in the framework of the "Trentingrana project" funded by the Trento province (Italy). The authors thank the Consortium of Dairy Factories of Trento province (CONCAST-Trentingrana, Spini di Gardolo, Italy) for supplying field data and Giorgio De Ros of the "Fondazione Edmund Mach" (San Michele all'Adige, Italy) for coordinating the project.

\section{REFERENCES}

Agabriel, C., B. Martin, C. Sibra, J. C. Bonnefoy, M. C. Montel, R. Didienne, and S. Hulin. 2004. Effect of dairy production systems on the sensory characteristics of Cantal cheeses: A plantscale study. Anim. Res. 53:221-234.

Aleandri, R., L. G. Buttazzoni, J. C. Schneider, A. Caroli, and R. Davoli. 1990. The effect of milk protein polymorphisms on milk components and cheese-producing ability. J. Dairy Sci. 73:241255.

Bellesia, F., A. Pinetti, U. M. Pagnoni, R. Rinaldi, C. Zucchi, L. Caglioti, and G. Palyi. 2003. Volatile components of Grana Parmigiano-Reggiano type hard cheese. Food Chem. 83:55-61.

Bertoni, G., L. Calamari, and M. G. Maianti. 2001. Producing specific milks for speciality cheeses. Proc. Nutr. Soc. 60:231-246.

Bittante, G., A. Cecchinato, N. Cologna, M. Penasa, F. Tiezzi, and M. De Marchi. 2011. Factors affecting the incidence of first-quality wheels of Trentingrana cheese. J. Dairy Sci. 94:3700-3707.

Bodyfelt, F. W., M. A. Drake, and S. A. Rankin. 2008. Development in dairy food sensory science and education: From student contests to impact on product quality. Int. Dairy J. 18:729-734.

Bonfatti, V., G. Di Martino, A. Cecchinato, L. Degano, and P. Carnier. 2010. Effects of $\beta$ - $\kappa$-casein (CSN2-CSN3) haplotypes, $\beta$-lactoglobulin $(B L G)$ genotypes, and detailed protein composition on coagulation properties of individual milk of Simmental cows. J. Dairy Sci. 93:3809-3817.

Boscaini, E., S. Van Ruth, G. Biasioli, F. Gasperi, and T. D. Mark. 2003. Gas chromatography olfactometry (GC-O) and proton transfer reaction-mass spectrometry (PTR-MS) analysis of the flavor profile of Grana Padano, Parmigiano Reggiano, and Grana Trentino cheeses. J. Agric. Food Chem. 51:1782-1790.

Bouamra-Mechemache, Z., and J. Chaaban. 2010. Determinants of adoption of Protected Designation of Origin label: Evidence from the French Brie cheese industry. J. Agric. Econ. 61:225-239.

Buchin, S., B. Martin, D. Dupont, A. Bonard, and C. Achilleos. 1999 Influence of the composition of Alpine highland pasture on chemical, rheological and sensory properties of cheese. J. Dairy Res. $66: 579-588$.

Cassandro, M., A. Comin, M. Ojala, R. Dal Zotto, M. De Marchi, L. Gallo, P. Carnier, and G. Bittante. 2008. Genetic parameters of milk coagulation properties and their relationships with milk yield and quality traits in Italian Holstein cows. J. Dairy Sci. 91:371-376.

Cecchi, F., R. Ciampolini, E. Ciani, and E. Mazzanti. 2007. Genetic variability of milk rheological parameters in Italian Friesian dairy cows. Milchwissenschaft 62:278-280.

Cecchinato, A., M. De Marchi, L. Gallo, G. Bittante, and P. Carnier. 2009. Mid-infrared spectroscopy predictions as indicator traits in breeding programs for enhanced coagulation properties of milk. J. Dairy Sci. 92:5304-5313.

Cologna, N., F. Tiezzi, M. De Marchi, M. Penasa, A. Cecchinato, and G. Bittante. 2010. Sources of variation of quality traits of herd bulk milk used for Trentingrana cheese production. Vol. 16, page 167 in Book of Abstracts of the 61st Annual Meeting of the European Association for Animal Production, Heraklion, Crete, Greece. EAAP, Rome, Italy. 
Comin, A., M. Cassandro, S. Chessa, M. Ojala, R. Dal Zotto, M. De Marchi, P. Carnier, L. Gallo, G. Pagnacco, and G. Bittante. 2008. Effects of composite $\beta$ - and $\mathrm{k}$-casein genotypes on milk coagulation, quality, and yield traits in Italian Holstein cows. J. Dairy Sci. 91:4022-4027.

Comin, A., M. Cassandro, M. Povinelli, and G. Bittante. 2005. Genetic aspects of milk coagulation properties in Italian Holstein cows. Ital. J. Anim. Sci. 4(Suppl. 2):10-12.

Costell, E. 2002. A comparison of sensory methods in quality control. Food Qual. Prefer. 13:341-353.

Coulon, J. B., A. Delacroix-Buchet, B. Martin, and A. Pirisi. 2005. Ruminant management and sensory characteristics of cheeses. Prod. Anim. 18:49-62.

Dal Zotto, R., M. De Marchi, A. Cecchinato, M. Penasa, M. Cassandro, P. Carnier, L. Gallo, and G. Bittante. 2008. Reproducibility and repeatability of measures of milk coagulation properties and predictive ability of mid-infrared reflectance spectroscopy. J. Dairy Sci. 91:4103-4112.

De Marchi, M., G. Bittante, R. Dal Zotto, C. Dalvit, and M. Cassandro. 2008. Effect of Holstein Friesian and Brown Swiss breeds on quality of milk and cheese. J. Dairy Sci. 91:4092-4102.

De Marchi, M., R. Dal Zotto, M. Cassandro, and G. Bittante. 2007. Milk coagulation ability of five dairy cattle breeds. J. Dairy Sci. 90:3986-3992.

De Marchi, M., C. C. Fagan, C. P. O'Donnell, A. Cecchinato, R. Dal Zotto, M. Cassandro, M. Penasa, and G. Bittante. 2009. Prediction of coagulation properties, titratable acidity, and $\mathrm{pH}$ of bovine milk using mid-infrared spectroscopy. J. Dairy Sci. 92:423-432.

Delahunty, C. M., and J. R. Piggott. 1995. Current methods to evaluate contribution and interactions of components to flavor of solid foods using hard cheese as an example. Int. J. Food Sci. Technol. 30:555-570.

Drake, M. A. 2004. ADSA Foundation Scholar Award: Defining dairy flavors. J. Dairy Sci. 87:777-784.

Drake, M. A. 2007. Invited review: Sensory analysis of dairy foods. J. Dairy Sci. 90:4925-4937.

Drake, M. A., M. D. Yates, and P. D. Gerard. 2008. Determination of regional flavor differences in US Cheddar cheeses aged for 6 mo or longer. J. Food Sci. 73:S199-S208.

Elortondo, F. J. P., P. Barcenas, G. Casas, J. Salmeron, and M. Albisu. 1999. Development of standardized sensory methodologies: Some applications to Protected Designation of Origin cheeses. Sci. Aliments 19:543-558.

Elortondo, F. J. P., M. Ojeda, M. Albisu, J. Salmeron, I. Etayo, and M. Molina. 2007. Food quality certification: An approach for the development of accredited sensory evaluation methods. Food Qual. Prefer. 18:425-439.

Feria-Morales, A. M. 2002. Examining the case of green coffee to illustrate the limitations of grading systems/expert tasters in sensory evaluation for quality control. Food Qual. Prefer. 13:355-367.

Foegeding, E. A., and M. A. Drake. 2007. Invited review: Sensory and mechanical properties of cheese texture. J. Dairy Sci. 90:16111624.

Franciosi, E., A. Pecile, A. Cavazza, and E. Poznanski. 2009. Microbiological monitoring of raw milk from selected farm in the Trentingrana region. Ital. J. Anim. Sci. 8(Suppl. 2):408-410.

Franciosi, E., L. Settanni, N. Cologna, A. Cavazza, and E. Poznanski. 2011. Microbial analysis of raw cows' milk used for cheese-making: Influence of storage treatments on microbial composition and other technological traits. World J. Microbiol. Biotechnol. 27:171-180.

Galgano, F., F. Favati, L. Lencioni, and M. Bertuccioli. 2001. Characterisation of a marketable cheese through the definition of its sensory profile. Case study: The Grana Padano cheese. Ind. Aliment. 40:1230-1237.

Gaya, P., E. Fernandez-Garcia, M. Medina, and M. Nunez. 2003. Seasonal variation in microbiological, chemical, textural and sensory characteristics during ripening of raw ewes' milk Castellano cheese. Milchwissenschaft 58:376-379.

Malacarne, M., A. Summer, E. Fossa, P. Formaggioni, P. Franceschi, M. Pecorari, and P. Mariani. 2006. Composition, coagulation properties and Parmigiano-Reggiano cheese yield of Italian Brown and Italian Friesian herd milks. J. Dairy Res. 73:171-177.

Martin, B., J. F. Chamba, J. B. Coulon, and E. Perreard. 1997. Effect of milk chemical composition and clotting characteristics on chemical and sensory properties of Reblochon de Savoie cheese. J. Dairy Res. 64:157-162.

Martin, B., D. Pomies, P. Pradel, I. Verdier-Metz, and B. Remond. 2009. Yield and sensory properties of cheese made with milk from Holstein or Montbeliarde cows milked twice or once daily. J. Dairy Sci. 92:4730-4737.

Martin, B., I. Verdier-Metz, S. Buchin, C. Hurtaud, and J. B. Coulon. 2005. How do the nature of forages and pasture diversity influence the sensory quality of dairy livestock products? Anim. Sci. 81:205-212.

Mendia, C., F. C. Ibanez, P. Torre, and Y. Barcina. 2000. Influence of the season on proteolysis and sensory characteristics of Idiazabal cheese. J. Dairy Sci. 83:1899-1904.

Ng-Kwai-Hang, K. F., I. Politis, R. I. Cue, and A. S. Marziali. 1989. Correlations between coagulation properties of milk and cheese yielding capacity and cheese composition. Can. Inst. Food Sci. Technol. 22:291-294.

Nielsen, R. G., M. Zannoni, F. Berodier, P. Lavanchy, P. C. Lorenzen, D. D. Muir, and H. K. Sivertsen. 1998. Progress in developing an international protocol for sensory profiling of hard cheese. Int. J. Dairy Technol. 51:57-64.

Noel, Y., Y. Ardo, S. Pochet, A. Hunter, P. Lavanchy, W. Luginbuhl, D. Le Bars, A. Polychroniadou, and L. Pellegrino. 1998. Characterisation of protected de nomination of origin cheeses: Relationships between sensory texture and instrumental data. Lait 78:569-588.

Oloffs, K., H. Schulte-Coerne, K. Pabst, and H. O. Gravert. 1992. Die Bedeutung der Proteinvarianten für genetische Unterschiede in der Käsereitauglichkeit der Milch. Zuchtungskunde 64:20-26.

Penasa, M., M. Cassandro, D. Pretto, M. De Marchi, A. Comin, S. Chessa, R. Dal Zotto, and G. Bittante. 2010. Short communication: Influence of composite casein genotypes on additive genetic variation of milk production traits and coagulation properties in Holstein-Friesian cows. J. Dairy Sci. 93:3346-3349.

Polentarutti, M., L. Piasenzotto, G. Comi, L. Conte, and A. Surmely. 2001. Influence of season on raw milk and on Montasio cheese aroma. Ind. Aliment. 40:1331-1342.

Salvadori Del Prato, O. 1994. Grana-Padano-Tradition and Technology. Dairy Ind. Int. 59:23-27.

Segato, S., S. Balzan, C. A. Elia, L. Lignitto, A. Granata, L. Magro, B. Contiero, I. Andrighetto, and E. Novelli. 2007. Effect of period of milk production and ripening on quality traits of Asiago cheese. Ital. J. Anim. Sci. 6(Suppl. 1):469-471.

Tornambè, G., A. Lucas, I. Verdier-Metz, S. Hulin, C. Agabriel, and B. Martin. 2005. Effect of production systems on sensory characteristics of PDO Cantal cheese. Ital. J. Anim. Sci. 4(Suppl. 2):248-250.

Vallas, M., H. Bovenhuis, T. Kaart, K. Pärna, H. Kiiman, and E. Pärna. 2010. Genetic parameters for milk coagulation properties in Estonian Holstein cows. J. Dairy Sci. 93:3789-3796. 